\title{
The ethics of science communication
}

\section{Fabien Medvecky and Joan Leach}

Abstract

What is it that really makes communicating science a good, moral thing to do? And are there limits to the potential 'goodness' of science communication? In this article, we argue it is time we consider what an ethics of science communication might look like. Not only will this help us figure out what doing the right, moral thing might be. It also invites us to think through one of the most perplexing, challenging and pressing question for this still emerging field: what are the core unifying features of science communication?

Keywords

Professionalism, professional development and training in science communication; Science communication: theory and models

Communicating science, we are often told, is an important thing to do. The public should be informed so it can make better decisions, the argument states.

More knowledge is better than less knowledge, right? Or, as the adage has it, we need 'knowledge for knowledge's sake'. All this gives science communication a sense of moral righteousness; science communication is a good moral thing to do. But let's pause here.

What is it that really makes communicating science a good, moral thing to do? And are there limits to the potential 'goodness' of science communication? Surely not all science is unquestioningly good (think biological weapons, for example). It would be strange to think that communicating the 'how-to' details for building a biological weapon is as ethically praiseworthy as communicating the 'how-to' details for building a weather station. So let us take step back and think about this: where does science communication's draw its moral grounding from? Is science communication a child of science, a child of journalism, a child of communication, or is it time it enters adulthood when it comes to its ethics.

As it turns out, working out the ethics of science communication does more than just help us figure out what doing the right, moral thing might be. It invites us to think through one of the most perplexing, challenging and pressing question for this emerging field: what are the core unifying features of science communication? And it is high time we tackle both the question of what the ethics of science communication are, and the question of what is the core of science communication. 
Consider the following cases.

Knowledge Brokers. The growth of 'knowledge broker' positions where the goal of science communication is to assist with access to knowledge among key stakeholders in a technical area is one where ethical issues are rife [Meyer, 2010]. Knowledge brokers direct attention to specific bodies of knowledge and away from others. Sometimes they do this in high stakes policy contexts, using some sort of Occam's Razor to find relevant information. What are the principles in use as they wield this razor?

Citizen Science. The growth of citizen science has brought ethical challenges as well as epistemic opportunities [Stilgoe, Lock and Wilsdon, 2014]. How should citizen scientists be recognised for their work? Is it ethical to call it science if no new knowledge is produced? Are the social hierarchies involved in citizen science leading to ethical problems? Who takes credit for the work (and which bits of the work?). And of course, who benefits? If citizen science is going to be seen as a powerful mode of science communication - in that the citizen actually learns about the science and does the science on their own terms - there is undone work in figuring out the ethical relationships among those engaged.

The (various) norms of science communication.
A reoccurring challenge for science communication is that it is a mix of various fields [Priest, 2010]. This is part of the strength of science communication, but it's also one of its weaknesses as these various fields sometimes pull in different directions. And working out the ethics of science communication exemplifies the latter. So where do we start? Given science communication's subject matter, the norms of science might provide us with a good starting point for guidance on ethical norms. Arguably, the best-established norms of science are the Mertonian norms commonly combined under the acronym CUDOS. These are: Communalism (scientific knowledg is owned in common by the whole scientific community); Universalism (the validity of scientific claims should be based on universal criteria and not on sociopolitical traits); Disinterestedness (scientific work should be pursued for the benefit of the common scientific enterprise, not for personal gain); and Organized Scepticism (scientific claims should be not be accepted until they have been critically examined and tested). While these norms aim to guide how science itself should be carried out, they also (in some cases) strike a chord with the aims of science communication. For example, the notion of scientific knowledge being commonly owned is a familiar refrain, though we might think it ought to be owned not just by the scientific community but also by society more broadly. At the same time, these norms say little of practical value for many of the questions we'd like guidance on. Having shared ownership over scientific knowledge doesn't mean it all needs to be communicated equally (recall the above mention of biological weapons). Nor do these norms say much about things such as the importance of timing in communication; communicating too early risks accusations of 'hype', and too late of 'covering up'.

Perhaps a more practical set of norms will help here, say by looking at journalistic ethics. There are a number of codes for journalistic ethics, and while some differences exists between them, they all share core elements [see SPJ.org, 2014]. 
These include truthfulness and accuracy in reporting (which requires journalists be as accurate as can be expected given their time frame, and that requires information is verified and independently fact-checked); the harm limitation principle (which required journalists weighs off the public's need for information against the potential harm of making that information public); and the principle of independence (which reminds journalists that their primary obligation is to serve the public).

While we might feel sympathy for these norms, in practice, it's not so simple. We have already mentioned the problem knowledge brokers as one area where ethical issue abound around independence. There is also the example of 'native content' and advertorials in science journalism [Carlson, 2015]. Native content is a style of advertising that matches the form and function of the platform in which it appear. For example, an article paid for and written by a university but that also acts as a form of advertising and might appear in a local newspaper. The article may be about almost any scientific field and may mention research from the local (advertising) university, along with other international research. The fact that it is a paid-for advertorial is not clearly evident as the style of the article reads like a normal article. So to whom is the communicator writing such content beholden to? Big institutions often fund science communication and this challenges the journalistic notion of independence.

An alternative potential set of norms comes from communication studies. The National Communication Association gives an example of what it understands to be the norms of communication in its set of ethical guidelines. These are premised on the view that "ethical communication enhances human worth and dignity by fostering truthfulness, fairness, responsibility, personal integrity, and respect for self and other." [National Communication Association, 1999]. Unlike journalistic ethics, which is concerned with the very practical questions of how we do morally good communication (in that case, via journalism), communication ethics is concerned with using communication as a force for good (defined in terms of enhanced in human integrity, responsibility etc). Again, this resonates with much of the motivations we often have for communicating science, especially the more democratic aspirations of two-way models. But consider the substantial work done in science communication on ways to persuade and charm audiences into 'accepting the science'. Indeed, questions have already been asked over the ethics of using narrative to this end [Dahlstrom and Ho, 2012]. Do pursuing these persuasive aims challenge the NCA's call for endorsing "freedom of expression, diversity of perspective, and tolerance of dissent"? Of course, it is also extraordinarily timely to ask how much 'tolerance' science communication as a field has or should have for varying kinds of dissent. Some science communication practitioners and theorists would have problems with "just say 'no' to vaccines" as viable dissent.

A real problem for science communication in the ethical space is that the field has a normative face and a descriptive one. In the case of vaccines, good research can describe the contours of dissent very well and even 'tolerate' dissent by describing various non-consensus positions and the warrants behind taking those positions. But, it is one thing to be pluralistic in describing dissent and another to be pluralistic in communicating various messages that arise from that dissent. This 
ethical problem has been around for 'technical' disciplines and was even described by Plato. Science Communication has some schooling in its own history to do. All this leaves science communication in a strange ethical space.

\section{Conclusion}

Science communication can't neatly call on any 'off-the shelf' ethical guides because fundamentally, science communication is neither science, nor journalism, nor straightforward communication. Science communication may be a relation to all these, but it is something else too. The question is exactly what is this 'something else'. And this is where ethical reflection really comes into its own. Working out an ethical base for science communication, requires we work out what is at the core of science communication and how science communication relates to these fields. In order for us to think about what kind of ethics we want for science communication, we also need to think about what kind of beast science communication is. And thinking about the ethics actually helps to define that beast. We think it time we open a discussion on both these issues.

References

Carlson, M. (2015). 'When news sites go native: Redefining the advertising-editorial divide in response to native advertising'. Journalism: Theory, Practice \& Criticism 16 (7), pp. 849-865. DOI: 10.1177/1464884914545441.

Dahlstrom, M. F. and Ho, S. S. (2012). 'Ethical Considerations of Using Narrative to Communicate Science'. Science Communication 34 (5), pp. 592-617. DOI: $10.1177 / 1075547012454597$.

Meyer, M. (2010). 'The Rise of the Knowledge Broker'. Science Communication 32 (1), pp. 118-127. DOI: 10.1177/1075547009359797.

National Communication Association (1999). NCA credo for ethical communication. URL: https://www .natcom.org/sites/default/files/pages/1999_Public_St atements_NCA_Credo_for_Ethical_Communication_November.pdf (visited on 22nd August 2017).

Priest, S. H. (2010). 'Coming of age in the academy? The status of our emerging field'. JCOM 9 (3), C06. URL: https://jcom. sissa.it/archive/09/03/Jcom090 $3 \% 282010 \% 29 \mathrm{C} 01 / \mathrm{Jcom} 0903 \% 282010 \% 29 \mathrm{C} 06$.

SPJ.org (2014). SPJ Code of Ethics. URL: http: //www . spj . org/ethicscode . asp (visited on 22nd August 2017).

Stilgoe, J., Lock, S. J. and Wilsdon, J. (2014). 'Why should we promote public engagement with science?' Public Understanding of Science 23 (1), pp. 4-15. DOI: $10.1177 / 0963662513518154$.

\section{Authors}

Fabien Medvecky is a lecturer in science communication at the University of Otago's Centre for Science Communication and is the president of the Science Communicators' Association of New Zealand. With a background in philosophy of science, and environmental economics, he previously lectured at the University of Queensland's program in science communication.

E-mail: fabien.medvecky@otago.ac.nz. 
Joan Leach is the Director of the Centre for the Public Awareness of Science at the Australian National University. Her research centers on public engagement with science, medicine and technology and she has published extensively about science communication in books, journals and the media. E-mail: joan.leach@anu.edu.au.

How to cite

Medvecky, F. and Leach, J. (2017). 'The ethics of science communication'. JCOM $16(04), \mathrm{E}$. 